\title{
Organizational Assessment: An Overlooked Approach To Managing Diversity And Addressing Racism In The Workplace
}

Brigid Trenerry, University of Western Sydney, Australia Yin Paradies, University of Melbourne, Australia

\begin{abstract}
Strategies to manage diversity and address racism within organizations are fast becoming routine practice. This is especially important given the demographic compositions of workforces are changing and evidence that racism is commonplace within workplaces and associated with a range of detrimental economic, social and health outcomes. In this paper, we consider organizational assessment as a largely overlooked approach to managing diversity and addressing racism in the workplace. Approaches to organizational assessment in the fields of diversity management and cultural competency are explored and critiqued before turning to a review of organizational assessment tools focused on managing diversity and/or addressing racism. A critical review of the eight tools that met the inclusion criteria led to the formulation of six key principles to guide the selection of organizational assessment tools.. Current organizational assessment tools lack an explicit focus on addressing systemic racism and require further refinement and testing in order to effectively manage diversity and address racism in the workplace.
\end{abstract}

Keywords: Workplace; Diversity Management; Racism; Organizational Assessment

\section{INTRODUCTION}

$\mathrm{n}$ recent times, there has been increasing impetus for employers to accommodate and manage diversity in the workplace (Cox, 1991). This has been driven by both the changing nature of workforce demographics, which has positioned workplace diversity as a business imperative (Cox, 1993; Lorbiecki \& Jack, 2000; R. R. Thomas, 1990) as well as policy and legislative changes that require equality of opportunity for women, people with disabilities and members of racial and ethnic minority groups (Liff \& Wajcman, 1996; Wrench, 2005). There has also been increasing recognition of the benefits of diversity which include: increased productivity, larger market share, innovative thinking and improved employee relations (Berman, Victorian Equal Opportunity and Human Rights Commission, \& Victorian Multicultural Commission, 2008; Nicholas et al., 2001); increased creativity and enhanced organizational performance (Adler, 1997; Burton, 1995; McLeod, Lobel, \& Cox, 1996; Richard, 2000); greater employee commitment and better customer satisfaction (Bertone, Leahy, \& Doughney, 2005; Kulik \& Roberson, 2008; Paradies et al., 2009; Triana, García, \& Colella, 2010). However, other studies have found that diversity can also reduce staff morale and productivity and provoke conflict between employees and managers (Kochan et al., 2003; Prasad, Mills, Elmes, \& Prasad, 1997; Roberson \& Kulik, 2007; Wrench, 2005). The impact of diversity on social identity and team development and performance within organizations has also been the focus of some academic research (Ely, 2004; Ely \& D. A. Thomas, 2001; Jackson, Joshi, \& Erhardt, 2003; Katz \& Kahn, 1978). On the whole, academic scholarship is mixed on the benefits of diversity within organizations, with a number of studies arguing that context, which includes how diversity is managed through management and human resource systems, plays a pivotal role (Kochan, et al., 2003; Prasad, et al., 1997; Richard, 2000; Soni, 2000) as does the interplay between racism and diversity within workplaces (Triana, García, \& Colella, 2010). 
Racism, which encompass any unfair and avoidable treatment resulting in unequal power, resources or opportunities across racial, ethnic, cultural and/or religious groups (Paradies, et al., 2009) has negative outcomes for individuals and society and is commonplace within workplaces (Beagan \& Etowa, 2009; Deitch et al., 2003; Dunn, 2003; Kessler, Mickelson, \& Williams, 1999; Rospenda, Richman, \& Shannon, 2009; Scarville, Button, Edwards, Lancaster, \& Elig, 1999; Schneider, Hitlan, \& Radhakrishnan, 2000; Shannon, Rospenda, Richman, \& Minich, 2009). Workplace racism has been associated with a range of detrimental outcomes, including: poor mental and physical health and wellbeing (De Castro, Rue, \& Takeuchi, 2010; Deitch, et al., 2003; Din-Dzietham, Nembhard, Collins, \& Davis, 2004; Rospenda, et al., 2009); problem drinking (Rospenda, et al., 2009); psychological distress (Krieger et al., 2011); reduced productivity and innovation (Berman, et al., 2008); reduced organizational commitment and employee perceptions of procedural injustice (Buttner, Lowe, \& Billings-Harris, 2010; Buttner \& Lowe, 2010; Triana, et al., 2010); reduced trust and job dissatisfaction (Holder \& Vaux, 1998); as well as increased cynicism, absenteeism and staff turnover (Buttner, et al., 2010; Buttner \& Lowe, 2010).

Strategies to manage diversity and address racism within organizations are fast becoming routine practice with various approaches adopted by human resource practitioners, managers and diversity experts. Academic study of diversity management techniques is also on the rise. However, despite their popularity, there is limited empirical support for the effectiveness of such strategies (Curtis \& Dreachslin, 2008; Dreachslin, Weech-Maldonado, \& Dansky, 2004; Ivancevich \& Gilbert, 2000; Kalev, Dobbin, \& Kelly, 2006). Even for diversity training, one of the most commonly undertaken activities (as well as a favored topic of research) there is limited evidence of overall effectiveness, although reviews have generally found positive impacts on participants (Beach et al., 2006; Bhawuk \& Brislin, 2000; Black \& Mendenhall, 1990; Chipps, Simpson, \& Brysiewicz, 2008; Kulik \& Roberson, 2008; Littrell \& Salas, 2005; Paluck, 2006; Shapiro, 2002). The literature has also found that diversity training is unlikely to have sustained positive effects if implemented in the absence of broader organizational accountability mechanisms and leadership (Bendick, Egan, \& Lofhjelm, 2001; Kalev, et al., 2006; Paradies, et al., 2009). Even if individual attitudes or behaviors change as a result of diversity training, the effects are likely to be short lived if organizational structures and policies have not adapted to reflect non-discriminatory norms.

Another strategy, which has received less academic attention, is organizational assessment. Commonly referred to as cultural competency organizational assessment or diversity audits, this approach allows workplaces to review and plan for improved practice across a range of organizational functions (Cox, 1993; Cross, Bazron, Dennis, \& Issacs, 1989; Fine, 1996; Kossek \& Zonia, 1993; R. R. Thomas, 1999). Mathews (1998, p. 179) argues that auditing diversity practices helps avoid 'quick-fix' solutions and enables meaningful change by gathering accurate data about organizational strengths and weaknesses and convincing managers that problems exist. Organizational assessment also provides the means to establish organizational accountability, by providing a framework for planning and the allocation of resources. Embedding organizational accountability is seen as essential to the implementation and ongoing viability of diversity practices (Cox, 1993). The process is usually guided by an assessment tool that allows organizations to establish where they are now in terms of current policy and practice, where they want to be and how they will move forward and evaluate progress. Organizational assessment tools usually consist of a series of best-practice statements and examples, which set a benchmark for assessment and planning. While the notion of 'best-practice' has been critiqued by some scholars as being only 'loosely' based on academic theories (Kalev, et al., 2006, p. 590), the literature attests to a consistency across tools, particularly when they are developed with a strong theoretical basis, empirically tested and context-relevant (Harper et al., 2006; Olavarria, Beaulac, Belanger, Young, \& Aubry, 2009).

The purpose of this paper is to consider organizational assessment as an overlooked approach to managing diversity and addressing racism in the workplace through a review of current scholarship and assessment tools. While organizational assessment is a well-developed approach in fields such as cultural competency, an explicit focus on managing diversity and addressing racism within a workplace context has not, to our knowledge, received sufficient attention. Diversity is a broad term that includes gender, race and ethnicity, disability, and sexual orientation. This paper focuses on diversity as it applies to race and ethnicity. Over two decades ago, Cox and Nkomo (1990) called for more research into the impact of race and racism within organizations. Despite increased knowledge on its prevalence, there is limited understanding of strategies to address racism in the workplace. Moreover, current discourses of diversity management and cultural competency lack an explicit focus on addressing systemic racism. 
This paper begins by exploring and critiquing different approaches to organizational assessment in the fields of diversity management, cultural competency and anti-racism. Organizational assessment tools that have been developed to manage diversity, foster cultural competency and/or address racism within the workplace are then reviewed before establishing key principles in the selection of organizational assessment tools. Our goal is to provide a better understanding of approaches to organization assessment, as well as their underlying principles and assumptions, across key literatures. On a practical level, we aim to assist organizations and employers in using available tools and resources to manage diversity and address racism in the workplace.

\section{APPROACHES TO ORGANIZATIONAL ASSESSMENT}

\section{Diversity Management}

Diversity management is defined as the planning and implementation of organizational systems and human resource practices to maximize the advantages of diversity while minimizing its disadvantages (Cox, 1993). Diversity management is considered by some to imply a focus on the whole organization, rather than targeted strategies for under-represented groups. The appeal of this approach is that it avoids some of the backlash effects of affirmative action because it seeks to create an environment where all employees can work to their full potential, including white males (Wrench, 2005). Also underpinning diversity discourses is a belief that business rather than moral reasons are necessary to support long-term change (R. R. Thomas, 1990; Wrench, 2005).

Organizational assessment within the diversity management paradigm tends to be developed and conducted by specialized diversity practitioners and consultants. The evidence-base underlying these for-profit programs is rarely available in the public domain, with some suggesting this evidence-base is limited (Fine, 1996; Ivancevich \& Gilbert, 2000). Perhaps due in part to this situation, limited reference to diversity organizational assessment or auditing was found in the diversity management literature. Located studies describe the process of undertaking an assessment as a useful starting point for planning diversity activity within organizations and identifying gaps in current practice (Cox, 1993; Dreachslin, 1999; Fine, Johnson, \& Ryan, 1990; Kossek \& Zonia, 1993; Mathews, 1998; R. R. Thomas, 1999). However, despite being recommended practice in human resource and organizational development theory (Cox, 1993), organizational assessment appears to have dropped off the diversity and research agenda in favor of other strategies. Such a lack may also result from a stronger focus on changing individual attitudes and behaviors rather than addressing structural issues (Kalev, et al., 2006). This may explain why diversity training, which is arguably easier to implement and measure, is currently the dominant approach.

\section{Cultural Competency}

The theoretical and practical development of organizational assessment is most clearly evident within the field of cultural competency. Cultural competency is now well-established as a theoretical concept and practice following several decades of development in a range of practice-based settings. Although cultural competency is a broad concept which includes other forms of diversity (Sue et al., 1998), the concept has mainly been applied in the context of cross-cultural interaction between diverse racial, ethnic, cultural, religious and linguistic groups. It can be defined as a set of congruent attitudes, practices, policies and procedures, and structures that come together in a system or agency and enables professionals to work more effectively in cross-cultural situations (Cross, et al., 1989, p. 13; Siegel, Haugland, \& Chambers, 2004). The field emerged in the context of health care provision. While the concept has since expanded to range of other settings including community-based and government organizations, many approaches to organizational assessment still have a strong foundation in health care delivery. This specificity of cultural competency has implications for how well organizational assessment in this field can be translated into other workplace settings.

Several systematic reviews have focused on approaches to cultural competency assessment and measurement (Gozu et al., 2007; Harper, et al., 2006; Kumas-Tan, Beagan, Loppie, MacLeod, \& Frank, 2007; Olavarria, et al., 2009). Similar to the critiques of diversity management, these reviews and other studies (LaVeist, Richardson, Richardson, Relosa, \& Sawaya, 2008; Office of Minority Health, 2001) suggest that current tools focus on assessing individuals rather than organizations. These individual self-assessment tools have largely taken the format of quantitative surveys that measure employee attitudes and behaviors. An advantage of this approach is that 
survey-based tools are relatively easy to utilize. Indeed a number of tools have proven validity and reliability in a range of practice-based settings (Gozu, et al., 2007). However, Kumas-Tan et al. (2007) found that many measures were based on problematic assumptions about what constitutes culturally competent practice. For example, widelyused tools focus on knowledge alone as an indicator of cultural competence, rather than considering attitudes and behaviors or what practitioners can do to improve practice.

Despite a growing recognition of a need for improved tools to assess organizational cultural competency, current approaches are still in development and on the whole lack a conceptual and empirical basis (Geron, 2002; Harper, et al., 2006). Harper (2006) maintains that a collective understanding of organizational cultural competence is yet to be established, that current instruments fail to operationalize cultural competence, and are in formats that are difficult for organizations to utilize. Olavarria et al. (2009) attribute the slower development of organizational assessment tools to the relatively recent establishment of frameworks and standards such as the U.S. Culturally and Linguistically Appropriate Standards (CLAS). The Office of Minority Health (2001) who developed these standards commented at the time that many tools had not been validated or were unsuitable for every organizational context. They called for more research into the development of assessment tools, including the validation of existing tools against national standards. A benefit of this approach is that tools based on national standards and indicators provide a framework from which to assess improvements in quality and performance (LaVeist, et al., 2008). Such standards are, however, not necessarily applicable to other national contexts. The application of cultural competence standards for non-health care settings also warrants further research.

\section{REVIEW METHODS}

A literature review of organizational assessment tools was conducted through a search of on-line databases including Business Source Complete, Informit, PubMed, PsychInfo, Scopus and Sociological Abstracts. The search was limited to published articles with abstracts between 1990 and August 2010 in English. Search terms included: workplace, employment, organization, diversity, cultural competency, racism, racial discrimination, prejudice, assessment, audit and tool (free text and MeSH subject category). Other subject/MeSH categories used were: cultural competency, self-assessment, needs assessment, organizational policy and workplace diversity. Also included, were relevant articles located through broader Scopus searches with key terms diversity, racism, racebased discrimination, racial discrimination, prejudice, anti-oppression/racism/bias/prejudice/discrimination, nondiscrimination, prejudice/racism/stereotype reduction/modify/education. Extensive Internet searches were also conducted, including terms such as organizational self-assessment OR audit tool, cultural competence/competency/responsiveness assessment OR audit tool, diversity assessment OR audit tool. Internet search hits were investigated until saturation of sources was reached. Reference lists of included articles and on-line material were searched and relevant materials referred to in these lists were obtained where possible. Contact was also made with key experts and academics in this field.

\section{Selection Of Tools}

Existing reviews of organizational assessment tools helped in identifying tools and determining inclusion criteria (Harper, et al., 2006; Hernandez, Nesman, Mowery, Acevedo-Polakovich, \& Callejas, 2009; Olavarria, et al., 2009). Several on-line compilations of organizational assessment tools were also found and reviewed.

Selection of tools was based on the following inclusion criteria:

- $\quad$ the tool focused at the organizational rather than the individual level;

- the tool assessed cultural competency, diversity and or racism/discrimination on multiple levels (domains) of an organization;

- $\quad$ the tool included operationalized domains and sound theoretical development;

- $\quad$ the tool was applicable to a range of organizational contexts; and

- the tool was publicly available and/or obtainable for this review. 
A total of 52 tools were located for this review (available upon request), with only eight tools meeting all of the above selection criteria. The majority of tools located for this review were found on-line rather than in published academic articles. Tools that did not have an explicit organizational/workplace-level focus through examining human resource and staffing issues, organizational structures, policies and practice, were excluded. Similarly, tools that only assessed one level of cultural competency (such as language services) were excluded. Frameworks and guidebooks, while generally useful, were excluded due to lack of operationalization and not having a user-friendly format. Checklists were also excluded due to their inability to assess organizational policy and practice in depth. While the large majority of assessment tools have been tailored to a particular organizational context, we excluded those that were too specific to be considered reproducible within other organizational contexts. Given that many tools were available, it was also important to consider which tools had undergone rigorous theoretical development or testing. Tools that did not provide sufficient information on their development were therefore excluded.

\section{RESULTS}

\section{Summary Of Included Tools}

A summary of the eight tools that met the inclusion criteria is detailed in Table 1. Information provided in the table includes the name and source of each tool; a description of how the tool was developed as well as validity and reliability; tool format and administration; and a review of key strengths. A more detailed summary of these assessment tools, including: their respective area of focus; domains covered; response format; administration; and validity is provided below.

Of the eight tools that met the inclusion criteria, seven focused on assessing cultural competency within health-care and community service organizations. All of the tools were developed in the U.S. or in Canada. Tools developed for general health care organizations included the Cultural Competency Self-Assessment Protocol (CCSAP) (Andrulis, Delbanco, Avakian, \& Shaw-Taylor, 1998), the Organizational Cultural Competence Assessment Profile (The Lewin Group, 2002) and Bowen's (2004) organizational assessment tool. The Cultural Competence Self-Assessment Questionnaire (CCSAQ) by Mason et al. (1995) was designed for use in child and adolescent mental health settings. The Cultural Competency Assessment Scale (CCAS) by Siegel et al. (2002) also focused on mental health services. The Cultural Competence and Linguistic Competence Policy Assessment (CLCPA) by the National Center for Cultural Competence (NCCC) (2006) was designed to support community health centers, while the Cultural Competency Assessment Tool was designed to assist government and communities agencies (Vancouver Ministry for Children and Families, 2002).

Most of the tools included in this review focused on assessing cultural competency within a health care context. Although cultural competency is increasingly being applied in other organizational settings, its origins within the health care sector means that some conceptual elements and operationalized domains may be of limited relevance to other organizational contexts. In particular, a key distinction of cultural competency organizational assessment tools is a tendency to prioritize service delivery functions. However, although diversity organizational assessment tools are more application to general workplace contexts, these tools were less readily available, and in some cases less developed in terms of conceptual foundations.

Only one diversity-based organizational assessment tool was included in this review. The ProMosaic ${ }^{\mathrm{TM}}$ II is a Diversity/Inclusion Assessment Tool developed by the Executive Leadership Foundation (2003). The tool was developed in consultation with senior leaders from major U.S. corporations and diversity practitioners. The tool focused on four components of diversity and inclusion: leadership and business rationale for diversity management; strategic planning; as well as execution and results/measurement for diversity planning. A key strength of the tool was that it integrated diversity concepts and theory with business processes and practices. The tool is also presented in a user-friendly format with detailed instructions.

We did not find any organizational assessment tools that had an explicit focus on addressing racism and discrimination in the workplace. Bowen's (2004) organizational assessment tool was the only tool included in this review which assessed anti-racism as part of an organization's philosophical and approach to addressing diversity. While not within the scope of this article, a number of international case studies have demonstrated some 
effectiveness in addressing racism in the workplace (Bennett, 2009; Creegan, Colgan, Charlesworth, \& Robinson, 2003; Griffith, Yonas, Mason, \& Havens, 2010; International Labour Organization (ILO), 2008; Leiderman \& Dupree, 2005; Potapchuk \& Aspen Institute Roundtable for Community Change, 2007). Although these studies have increased our understanding of how to address racism through organizational change they do not provide guidance on effective approaches to organizational assessment.

\section{Domains Covered}

A domain is defined as an area of practice identified for assessing an organization's progress in terms of cultural competency (Siegel, et al., 2002). Adapting a typology developed by Harper et al. (2006), the content covered by organizational assessment tools in this review are presented below in relation to five domains: human resource practice; organizational values and commitment; organizational strategy, policy, procedures and governance; diversity/cultural competency training; as well as planning, monitoring and evaluation.

Human resource practice such as recruitment, retention and promotion of staff were covered in all of the tools reviewed. This highlights the importance of workplace employment practices in building workforce diversity and cultural competency. Six tools included human resource practices as a separate domain (Bowen, 2004; Mason, 1995; NCCC, 2006; Siegel, et al., 2002; The Lewin Group, 2002; Vancouver Ministry for Children and Families, 2002). In the ProMosaic ${ }^{\mathrm{TM}}$ II diversity tool (Executive Leadership Foundation, 2003) assessment of human resource practices is the main purpose of the tool, while Andrulis, et al. (1998) covers human resource practice as an aspect of organizational approaches to diversity.

Many of the tools reviewed included a domain that assessed organizational values and commitment to diversity or cultural competency. Andrulis et al. (1998) and Bowen (2008) conceptualize this domain as the profile of the organization. Similarly, the NCCC (2006) includes a domain called organizational philosophy, defined as commitment to the provision of culturally competent services, including the extent to which this commitment demonstrated within organizational policy. The CCAS includes commitment to cultural competence as a domain (Siegel, et al., 2004), while the Lewin Group (2002) includes a domain on organizational values. Similarly, the Vancouver Ministry for Children (2002) considers an organization's foundation statements and documents as evidence of a commitment to organizational cultural competency. The ProMosaic ${ }^{\mathrm{TM}}$ II conceptualizes this as organizational leadership commitment and the business rationale for diversity (Executive Leadership Foundation, 2003).

Organizational strategy, policy, procedures and governance structures are covered as a specific domain in some tools. The Lewin Group (2002) include a domain on governance, which covers goal-setting, policy-making and other oversight mechanisms. The CCSAQ also includes a section on organizational policy and procedures (Mason, 1995) as does the assessment tool by the Vancouver Ministry for Children and Families (2002). All other tools included a review of organizational strategy, policy, procedures or governance structures within a domain of the tool (Andrulis, et al., 1998; NCCC, 2006; Siegel, et al., 2002) or in the process of administering the tool (Bowen, 2004)

Cultural competency or diversity training/education and staff development was covered as a separate domain in four of the tools (Bowen, 2004; Siegel, et al., 2002; The Lewin Group, 2002; Vancouver Ministry for Children and Families, 2002). Some aspect of staff training or development was incorporated in the remaining tools (Andrulis, et al., 1998; Executive Leadership Foundation, 2003; Mason, 1995; NCCC, 2006)

Data collection, evaluation and research practices (e.g. planning, monitoring and evaluation measures) were also included as a domain in two of the tools (Bowen, 2004; Executive Leadership Foundation, 2003) or included as a component of other domains in the remaining tools (Andrulis, et al., 1998; Mason, 1995; NCCC, 2006; Siegel, et al., 2002; The Lewin Group, 2002; Vancouver Ministry for Children and Families, 2002). 
Table 1: Review Of Organizational Assessment Tools

\begin{tabular}{|c|c|c|c|}
\hline Name of tool & Development/validity & Format/administration & Review (key principles) \\
\hline $\begin{array}{l}\text { The Cultural } \\
\text { Competence Self- } \\
\text { Assessment Protocol } \\
\text { for Health Care } \\
\text { Organizations and } \\
\text { Systems: Andrulis, et } \\
\text { al. (1998) }\end{array}$ & $\begin{array}{ll}\text { - } & \text { Based on Cross et al.'s } \\
\text { (1998) cultural continuum } \\
\text { model } \\
\text { - } & \text { Developed for health care } \\
\text { organizations } \\
\text { - } & \text { Content validity } \\
\text { - } & \text { Reflect majority of U.S. } \\
\text { cultural competency } \\
\text { standards and indicators } \\
\text { (Olavarria, et al., 2009) }\end{array}$ & $\begin{array}{ll}\text { - } & 122 \text { items } \\
\text { - } & \text { Yes/No, Likert (1-5) and } \\
\text { short descriptions } \\
\text { - } \quad \text { Interview questions } \\
\text { Step by step instruction on } \\
\text { how to administer the tool, } \\
\text { including the development of } \\
\text { an assessment committee to } \\
\text { lead the assessment process. }\end{array}$ & $\begin{array}{ll}\text { - } & \text { Strong theoretical } \\
\text { development } \\
\text { - } & \text { Content validity } \\
\text { - } & \text { Range of response } \\
& \text { formats } \\
\text { - } & \text { Practical and feasible } \\
\text { - } & \text { Not based on self- } \\
& \text { assessment }\end{array}$ \\
\hline $\begin{array}{l}\text { Assessing the } \\
\text { responsiveness of } \\
\text { health care } \\
\text { organizations to } \\
\text { culturally diverse } \\
\text { groups: Bowen (2004) }\end{array}$ & $\begin{array}{l}\text { Developed following } \\
\text { international review of } \\
\text { cultural competence, health } \\
\text { care access and health } \\
\text { disparities literature, } \\
\text { standards and existing } \\
\text { organizational assessment } \\
\text { instruments } \\
\text { Piloted at a large health } \\
\text { care organization but need } \\
\text { for further testing to } \\
\text { explore generalizability to } \\
\text { other settings }\end{array}$ & $\begin{array}{l}\text { Yes/No, short description, } \\
\text { tabulated } \\
\text { - } \quad \text { Includes document review } \\
\text { Includes interviews questions }\end{array}$ & $\begin{array}{l}\text { - } \begin{array}{l}\text { Strong theoretical } \\
\text { development }\end{array} \\
\text { Includes dimensions (of } \\
\text { organizational } \\
\text { philosophies and } \\
\text { approaches to addressing } \\
\text { diversity) as well as } \\
\text { domains } \\
\text { A range of response } \\
\text { formats (including } \\
\text { comprehensive } \\
\text { document review } \\
\text { component) } \\
\text { Not based on self- } \\
\text { assessment }\end{array}$ \\
\hline $\begin{array}{l}\text { ProMosaic }{ }^{\mathrm{TM}} I I, \\
\text { Diversity/Inclusion } \\
\text { Assessment Tool: } \\
\text { Executive Leadership } \\
\text { Foundation (2003) }\end{array}$ & $\begin{array}{l}\text { Developed over } 5 \text { years, } \\
\text { with advice from senior } \\
\text { leaders of major U.S. } \\
\text { (Fortune 500) companies } \\
\text { and diversity practitioners }\end{array}$ & $\begin{array}{l}\text { - } 36 \text { items } \\
\text { - } \quad \text { Ses/No answers } \\
\text { Scoring Guide for each item, } \\
\text { ranging from zero (area not } \\
\text { addressed) to five (exceeds } \\
\text { expected) } \\
\text { Administration via several } \\
\text { internal expects in each of } \\
\text { the assessment areas and that } \\
\text { questions will require } \\
\text { research and information } \\
\text { gathering }\end{array}$ & $\begin{array}{l}\text { - } \begin{array}{l}\text { Strong theoretical and } \\
\text { practice-based } \\
\text { development }\end{array} \\
\text { - } \quad \begin{array}{l}\text { Focused on workplace } \\
\text { diversity }\end{array} \\
\text { - } \quad \text { A range of response } \\
\text { formats } \\
\text { - } \\
\text { Practical and feasible } \\
\text { Not based on self- } \\
\text { assessment }\end{array}$ \\
\hline $\begin{array}{l}\text { Cultural Competence } \\
\text { Self-Assessment } \\
\text { Questionnaire: Mason } \\
\text { (1995) }\end{array}$ & $\begin{array}{l}\text { - } \begin{array}{l}\text { Developed for health and } \\
\text { human services }\end{array} \\
\text { - } \quad \text { Content validity supported } \\
\text { by literature and expert } \\
\text { review } \\
\text { - } \\
\text { Acceptable reliability }\end{array}$ & $\begin{array}{l}\text { Four- point Likert scale, } \\
\text { short description questions } \\
\text { Two versions of the tool: one } \\
\text { for employees involved in } \\
\text { service delivery (79 items) } \\
\text { and one for administrative } \\
\text { staff (60 items). } \\
\text { Collects demographic } \\
\text { information in additional (13 } \\
\text { item) survey } \\
\text { Administered as a } \\
\text { questionnaire to individual } \\
\text { employees } \\
\text { Includes scoring based on } \\
\text { five subscales. }\end{array}$ & 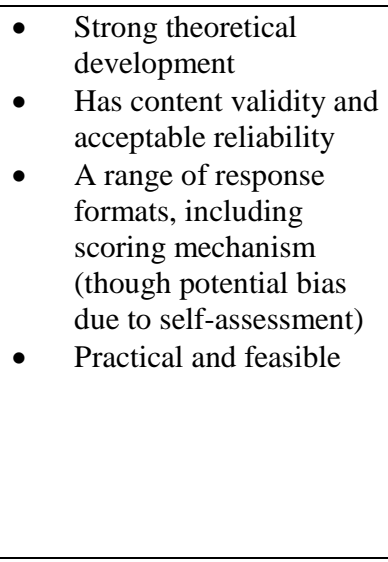 \\
\hline
\end{tabular}


Table 1: Continued

\begin{tabular}{|c|c|c|c|}
\hline Name of tool & Development/validity & Format/administration & Review (key principles) \\
\hline $\begin{array}{l}\text { Cultural and } \\
\text { Linguistic } \\
\text { Competence Policy } \\
\text { Assessment: National } \\
\text { Center for Cultural } \\
\text { Competence (2006) }\end{array}$ & $\begin{array}{l}\text { Developed at request of } \\
\text { Bureau of Primary Health } \\
\text { Care, Health Resources and } \\
\text { Services Administration } \\
\text { and the U.S. Department of } \\
\text { Health and Human Service } \\
\text { and designed for } \\
\text { community health centers } \\
\text { No information provided } \\
\text { on empirical testing }\end{array}$ & $\begin{array}{ll}\text { - } & 51 \text { items } \\
\text { - } & \text { Four- point Likert scale, } \\
\text { checkbox for supporting } \\
\text { policies/documents. } \\
\text { Tabulated to provide } \\
\text { information for each } \\
\text { designated cultural group } \\
\text { Collects demographic } \\
\text { information on an additional } \\
\text { survey (12 items) } \\
\text { Can be administered to all } \\
\text { agency personal or a sample } \\
\text { of staff from different } \\
\text { departments }\end{array}$ & 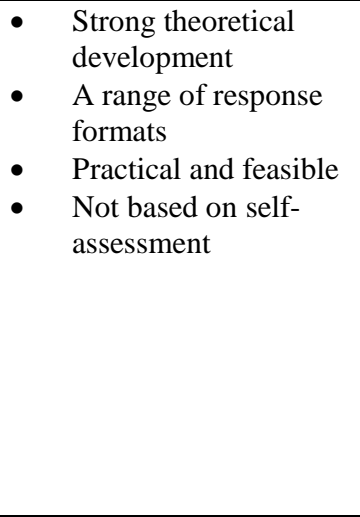 \\
\hline $\begin{array}{l}\text { Cultural Competency } \\
\text { in Mental Health } \\
\text { Systems of Care: } \\
\text { Selection and } \\
\text { Benchmarking of } \\
\text { Performance } \\
\text { Measures: Siegel, et al } \\
(2002)\end{array}$ & 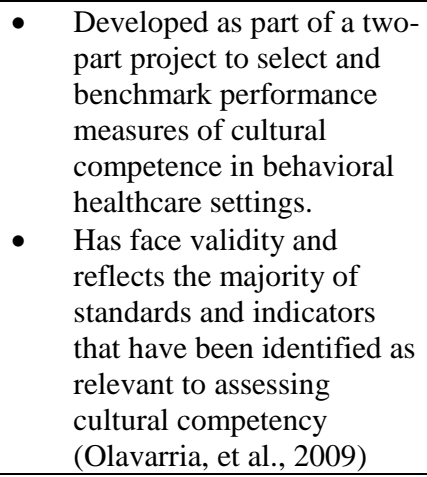 & $\begin{array}{ll}\text { - } & \text { Five-point Likert Scale } \\
\text { - } & \text { Tabulated worksheet } \\
\text { - } & \text { Scoring mechanism } \\
\text { - } & \text { Administered by } \\
& \text { knowledgeable or senior } \\
& \text { person(s) within the agency }\end{array}$ & 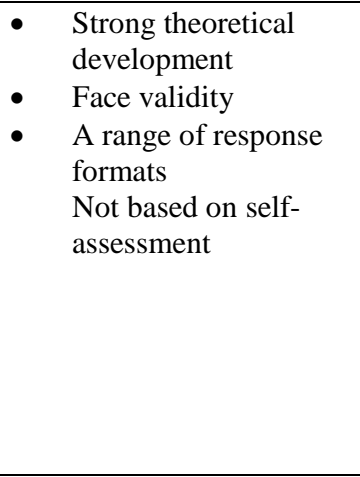 \\
\hline $\begin{array}{l}\text { Indicators of Cultural } \\
\text { Competence in Health } \\
\text { Care Delivery } \\
\text { Organizations: An } \\
\text { Organizational } \\
\text { Cultural Competence } \\
\text { Assessment Profile: } \\
\text { The Lewin Group } \\
(2002)\end{array}$ & $\begin{array}{l}\text { Developed through } \\
\text { literature review and } \\
\text { technical expert panel of } \\
\text { cultural competency and } \\
\text { diversity experts } \\
\text { Site visits to health care } \\
\text { facilities were conducted to } \\
\text { test the instrument. }\end{array}$ & $\begin{array}{l}\text { - Tabulated worksheet } \\
\text { Tool is structured as an } \\
\text { analytic or organizing } \\
\text { framework. Progress in } \\
\text { cultural competency is } \\
\text { measured against each set of } \\
\text { indicators }\end{array}$ & $\begin{array}{ll}\text { - } & \text { Strong theoretical } \\
\text { development } \\
\text { - } & \text { A range of response } \\
\text { formats, includes } \\
\text { structure, process and } \\
\text { outcome indicators } \\
\text { - } \quad \text { Practical and feasible } \\
\text { - } \\
\text { Not based on self- } \\
\text { assessment }\end{array}$ \\
\hline $\begin{array}{l}\text { Cultural Competency } \\
\text { Assessment Tool: } \\
\text { Vancouver Ministry } \\
\text { for Children and } \\
\text { Families (2002) }\end{array}$ & $\begin{array}{l}\text { Developed to assist the } \\
\text { Vancouver region of the } \\
\text { Ministry for Children and } \\
\text { Families and community } \\
\text { based agencies in } \\
\text { becoming more culturally } \\
\text { competent } \\
\text { Piloted in three sites }\end{array}$ & $\begin{array}{ll}- & \text { Tabulated worksheet } \\
\text { - } & \text { Likert (1-5) ranking and } \\
\text { space for written comments } \\
\text { against a criteria statement } \\
\text { for the area of impact } \\
\text { - Can be administered } \\
\text { internally or by an external } \\
\text { assessor }\end{array}$ & 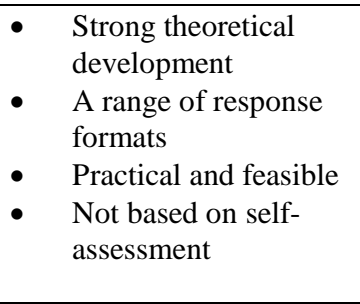 \\
\hline
\end{tabular}

\section{Response Format}

The tools assessed for this review used a variety of response formats, ranging from yes/no to Likert scales and short answers/descriptions as well as interview questions. All except two of the tools (Bowen, 2004; The Lewin Group, 2002) included a Likert scale (Andrulis, et al., 1998; Executive Leadership Foundation, 2003; Mason, 1995; NCCC, 2006; Siegel, et al., 2004; Vancouver Ministry for Children and Families, 2002).Yes/no answers were also a common response format for many of the tools, with three tools using this approach (Andrulis, et al., 1998; Bowen, 2004; Executive Leadership Foundation, 2003). In addition, two tools included short description questions or space for additional questions or comments (Andrulis, et al., 1998; Bowen, 2004). 
Three of the tools included a tabulated worksheet for recording responses, either as the main format for the tool (Bowen, 2004; The Lewin Group, 2002; Vancouver Ministry for Children and Families, 2002) or as a component of the tool (NCCC, 2006). The Lewin Group (2002) tool also provided indicators, including structure, process and outcome indicators for each level of organizational assessment.

Two of the tools included interview questions, which could supplement the information collected through the main body of the tool (Andrulis, et al., 1998; Bowen, 2004). Two tools collected demographic information about employees (Mason, 1995; NCCC, 2006). A further two tools included a checkbox for supporting policies and documents (Executive Leadership Foundation, 2003; NCCC, 2006).

The use of scoring guides was a feature of two tools included in this review. The CCSAQ included a guide to score and interpret responses across the whole organization (Mason, 1995). Results could also be calculated for individuals completing the questionnaire. The ProMosaic ${ }^{\mathrm{TM}}$ II also included a score totaled for each domain and the overall organization (Executive Leadership Foundation, 2003).

\section{Administration}

Methods for administering the tool varied depending on format. Those that used a Likert scale were mostly administered as a survey to relevant employees encompassing a variety of different roles within the organization. For example, the CCSAQ is administered as a questionnaire and includes two versions; one for employees involved in direct service delivery and the other for administrative staff (Mason, 1995). The CLCPA can be administered to all agency personnel or a sample of staff from various organizational departments (NCCC, 2006). Similarly, the CCAS can be administered to various staff within the organization (Siegel, et al., 2004).

Three tools recommended the establishment of an assessment committee representing key functions or departments within the organization (as well as independent external parties) to implement the tool (Andrulis, et al., 1998; Executive Leadership Foundation, 2003; NCCC, 2006). Tools in a tabulated format also provide a mechanism for the organization to gather data and arrive at consensus about what is documented in the tool (Bowen, 2004; The Lewin Group, 2002). Siegel, et al. (2002) suggests that their tool is administered by senior management or knowledgeable persons within the organization.

\section{Validity And Reliability}

The CCSAP by Andrulis et al. (1998) is frequently cited in the assessment literature as reflecting the majority of cultural competency standards and indictors developed in the U.S. The tool has been shown to have content validity, in that it accurately measures what it has been designed to measure (Olavarria, et al., 2009). The CCSAQ has also demonstrated content validity as well as reliability, with the majority of subscales having internal consistency (Mason, 1995). According to Olavarria, et al. (2009), the CCAS by Siegel, et al. (2002) is the most comprehensive tool in terms of its coverage of U.S. cultural competency standards.

Other tools such as those by Bowen (2004) and The Lewin Group (2002) have been field tested at health care facilities. Similarly, the Cultural Competency Assessment Tool has been piloted in three sites (Vancouver Ministry for Children and Families, 2002). The ProMosaic ${ }^{\mathrm{TM}}$ II has undergone extensive development with practitioners, including senior leaders of major U.S corporations and diversity practitioners (Executive Leadership Foundation, 2003). However, no information on its validity and reliability was provided. The CLCPA has also undergone extensive development with various government health agencies but no information on empirical testing was available (NCCC, 2006).

\section{DISCUSSION}

\section{Principles To Guide The Selection Of Organizational Assessment Tools}

Based on this review, six key principles were developed to guide the selection of organizational assessment tools to manage diversity and address racism in the workplace. These are: theoretical and empirical development; 
operationalized domains; practicality and feasibility of implementation; context relevance; a range of response formats; and moving beyond self-assessment.

\section{Theoretical And Empirical Development}

One of the most important principles to guide the selection of organizational assessment tools is prioritizing tools with a strong theoretical basis. Ideally, tools would also have undergone some level of empirical testing. Validity, which refers to the extent to which a measurement corresponds to the concept it attempts to measure, is perhaps the most important attribute of any empirical measure (Geron, 2002). Reliability refers to the consistency of measurement including the extent to which results can be reproduced by different people or across time (Geron, 2002). As noted in this review, while there are currently several organizational assessment tools available, very few have been empirically tested.

One explanation for the current lack of psychometric data on existing tools is the challenge of measuring complex and multi-layered concepts such as cultural competency, diversity and racism. Both the meaning of these terms and the terminology itself are complex and contested. Furthermore, there is no accepted conceptual framework for organizing these multifaceted components (Geron, 2002). Unlike survey-based instruments, it is more difficult to assess organizational assessment tools in terms of quantitative measures of validity and reliability. Therefore, what is important is that tools have a strong theoretical basis as well as being relevant, practical and feasible (Olavarria, et al., 2009). Three of the tools included in this review, the CCSAP (Andrulis et al. 1998), the CCSAQ (Mason 1995) and the CCAS (Siegel et al. 2002) were assessed by Olavarria et al. (2009) as consistent with the theoretical development of cultural competency standards and indicators.

\section{Operationalized Domains}

Another consideration for the selection of assessment tools is the inclusion of operationalized domains. Operationalization is the process of turning abstract concepts into observable and measurable quantities. Put more simply, operationalization is the process of taking a concept such as cultural competency from theory to action (Wu \& Martinez, 2006). For this review, the operationalization of cultural competency, diversity and/or racism within practice-settings was a specific inclusion criterion for assessment tools. A number of other located tools covered the literature comprehensively but functioned as guides rather than including specific items that could be assessed.

\section{Practicality And Feasibility Of Implementation}

Another challenge for measuring concepts like cultural competence, diversity and racism is to reliably capture their meaning in a way that is both practical and feasible to implement (Geron, 2002). This includes characteristics such as the user-friendliness of the tool and whether academic concepts have been translated into terms that are relevant to decision-makers who are operating within the constraints and opportunities of their particular and unique organizational contexts.

\section{Context Relevance}

There is not a one size fits all assessment tool that can be applied uniformly across organizations and settings (Olavarria, et al., 2009). This is reflected in the tools reviewed here, which have largely been developed for a specific sector or unique organizational setting (Harper, et al., 2006). Even the three most comprehensive U.S. based tools reviewed by Olavarria et al. (2009) did not cover all of the U.S. standards for organizational cultural competence. Therefore, rather than aiming for a one-size-fits all tool, organizations can either accept the limitations of existing tools, or use a combination of different tools relevant to organizational contexts and objectives (Olavarria, et al., 2009).

\section{A Range Of Response Formats}

Another key principle that emerged in the selection of assessment tools is variety in the response format. How data are collected through the tool has important implications for the depth and breadth of information assessed 
and the potential for bias. The tools included in this review used a range of response formats, including Likert scales, yes/no responses, short answer questions, a tabulated format, as well as interview/focus group questions. Some tools used all of these response formats, while for others only Likert scales or a tabular format were used.

Tools that use a variety of response formats and include multiple methods for data collection are likely to more accurately reflect actual practice. Tools that only include yes/no answers and do not provide space for further reflection or analysis may relegate the tool to a 'tick box' assessment, which creates a tendency for a more tokenistic responses. Likert scales aim to provide an indication of organizational assessment against a continuum. This may be useful for getting a better sense of where an organizational is currently placed in relation to a particular practice and in this way, provides more detail than a simple yes/no response. Likert scales may also be used as a scoring device. However, the criterion for assessment on a Likert scale and resultant scores are largely subjective and it is unclear exactly what a particular score indicates. Even as a summary score to assess change over time in the same organization, such quantitative scores are limited in their ability to assess improvement in concepts as complex as cultural competency, diversity and racism. Furthermore, Likert scales do not necessarily allow for further reflection and discussion.

Many of the tools included in this review recommend an assessment committee to administer and implement the tool. This was particularly true of those tools in a tabulated format, where the tool functions as a worksheet that guides discussion and analysis. Through an assessment committee, a number of people within the organization are responsible for coordinating and overseeing the assessment process, thus helping to prevent bias.

Other strategies for collecting information include a document review process, environmental scans (e.g. a walk-through of the physical environment) and interviews or focus groups with employees. The involvement of external parties can further assist this process by providing an independent evaluation of documents and data collected through the tool. For example, in an interview or focus group process, staff may be more open with an independent assessor than with a fellow employee (Vancouver Ministry for Children and Families, 2002).

\section{Moving Beyond Self-Assessment}

Another important consideration in the selection of organizational assessment tools is the method of administration. Given the potential for social desirability bias, tools that go beyond self-assessment are more likely to collect accurate data. Organizational assessments that move beyond self-assessment include a process for documenting and discussing practices, processes and outcomes. Absent of strong power dynamics, a committee to guide the assessment process supports multiple perspectives is preferable to reliance on an individual staff member. Gathering data through document review or interviews/focus groups with staff also provides a broader view of the organization where external parties may therefore play a role in reducing bias by providing an independent voice and perspective to the assessment process.

\section{CONCLUSION}

Despite an increasing focus on diversity management and cultural competency within organizations, several studies have shown that these practices have not improved health outcomes or reduced racial inequalities and systemic racism within workplaces (Beach et al., 2005; Brach \& Fraser, 2000; Griffith, Childs, Eng, \& Jeffries, 2007; Lie, Lee-Rey, Gomez, Bereknyei, \& Braddock, 2011; Wrench, 2005).

Organizational assessment has been recognized as an important strategy in both diversity management and cultural competency literature, as both a planning tool and a means to establish organizational accountability (Cox, 1993; Cross, et al., 1989; Mathews, 1998; R. R. Thomas, 1999). Publicly available organizational assessment tools are notably lacking in the diversity field. Current approaches to organizational assessment within cultural competence literature and diversity management lack an explicit focus on addressing systemic racism. Given the prevalence of racism within workplaces as well as its considerable social, economic and health impacts (Deitch, et al., 2003; Kessler, et al., 1999; Rospenda, et al., 2009; Shannon, et al., 2009), we propose that current approaches to organizational assessment require a stronger focus on assessing and addressing racism. An anti-racism perspective recognizes that in order to ensure that workplace environments are fair, equitable and inclusive for all, 
organizational assessment approaches to managing diversity and increasing an organization's cultural competency must include a focus on racism.

Despite measurement challenges, this review demonstrates some consistency in the domains covered by organizational assessment tools. This points to congruence in definitions and approaches to organizational assessment in the fields of cultural competency and diversity management (Harper, et al., 2006). Further research is required to ensure that domains used in current organizational assessment tools are consistent with theoretical and practice-based standards. Moreover, as an emerging area of research, the development of tools and resources will also inform the development of practice-based standards.

In embarking on an organizational assessment, there is a need to ensure that findings from such assessments inform rather than replace action. Just because an organization is committed to being a diverse organization does not necessarily mean that they are one (Ahmed, 2006). Reflecting on developments in the U.K., where public bodies are required to have a race equality and action plan, Ahmed (2006, pp. 108-109) notes that the process of developing race-equality policies 'quickly got translated into being good at race equality.' Similarly, in undertaking an organizational assessment, what is essential then is not the process itself but the action that it generates. Accountability is therefore at the heart of this disjuncture between assessment, policy and practice. Organizational assessments are an important starting point as well as a process to implement and measure change, but should not be mistaken for the goal in itself. The real test of such undertakings is the extent to which organizational commitments to managing diversity and addressing racism are put into practice. As such, further research is required to determine the extent to which assessment tools actually improve organizational cultural competence and diversity practice (Harper, et al., 2006).

\section{ACKNOWLEDGEMENTS}

This paper is based on a report commissioned by the Victorian Health Promotion Foundation (Trenerry, Franklin, \& Paradies, 2010). Thanks to Kim Webster who provided comments on the initial report. Brigid Trenerry is supported by an Australian Research Council scholarship. Yin Paradies is supported by a University of Melbourne McKenzie Fellowship.

\section{AUTHOR INFORMATION}

Brigid Trenerry graduated from the University of Melbourne in 2005 with a Bachelor of Arts degree (Honours) in Political Science. She is currently completing her doctorate in the area of workplace diversity and anti-racism in the School of Social Sciences and Psychology, University of Western Sydney. Prior to this, she worked in a range of community and philanthropic organisations and continues her involvement in the community-based sector. E-mail: btrenerry@vichealth.vic.gov.au. Corresponding author.

Dr Yin Paradies is a Senior Research Fellow and head of the Anti-racism and Diversity Studies Program at the McCaughey Centre in the School of Population Health, University of Melbourne. Dr Paradies has qualifications in mathematics and computer science, medical statistics, public health and social epidemiology. He conducts research on the health, social and economic effects of racism as well as anti-racism theory, policy and practice. E-mail: yinp@unimelb.edu.au.

\section{REFERENCES}

1. Adler, N. (1997). International dimensions of organizational behaviour. Cincinnati, Ohio: South Western College Publishing.

2. Ahmed, S. (2006). The Nonperformativity of Antiracism. Meridians: feminism, race, transnationalism, 7(1), 104-126.

3. Andrulis, D., Delbanco, B., Avakian, L., \& Shaw-Taylor, Y. (1998). The Cultural Competence SelfAssessment Protocol for Health Care Organizations and Systems. Retrieved from http://erc.msh.org/provider/andrulis.pdf 
4. Beach, M. C, Price, E. G., Gary, T. L., Robinson, K. A., Gozu, A., Palacio, A., . . Cooper, L. A. (2006). Improving health care quality for racial/ethnic minorities: a systematic review of the best evidence regarding provider and organization interventions. BMC Public Health 6, 104-111.

5. Beach, M. C., Price, E. G., Gary, T. L., Robinson, K. A., Gozu, A., Palacio, A., ... Cooper, L. A. (2005). Cultural Competence: A Systematic Review of Health Care Provider Educational Interventions. Medical Care, 43, 356-373.

6. Beagan, B. L., \& Etowa, J. (2009). The impact of everyday racism on the occupations of African Canadian women. The Canadian Journal of Occupational Therapy, 76(4), 285-293.

7. Bendick, M., Egan, M. L., \& Lofhjelm, S. M. (2001). Workforce diversity training: From antidiscrimination compliance to organisational development. Human Resource Planning, 24, 10-25.

8. Bennett, T. (2009). New ways of promoting equality and diversity in the workplace: The role of the union equality representative. Equal Opportunities International, 28(5), 443-447.

9. Berman, G., Victorian Equal Opportunity and Human Rights Commission, \& Victorian Multicultural Commission. (2008). Harnessing diversity: addressing racial and religious discrimination in employment. Melbourne: Victorian Multicultural Commission and the Victorian Equal Opportunity \& Human Rights Commission.

10. Bertone, S., Leahy, M., \& Doughney, J. (2005). Equal Opportunity in the Victorian Public Sector: Working towards Equity in Cultural Diversity: Victoria University: Work and Policy Research Unit, School of Applied Economics.

11. Bhawuk, D. P. S., \& Brislin, R. W. (2000). Cross-cultural Training: A Review. Applied Psychology: An International Review, 49, 162-191.

12. Black, J. S., \& Mendenhall, M. (1990). Cross-Cultural Training Effectiveness: A Review and a Theoretical Framework for Future Research. The Academy of Management Review, 15, 113-136.

13. Bowen, S. (2004). Assessing the responsiveness of health care organizations to culturally diverse groups. Ph.D. thesis, University of Manitoba.

14. Bowen, S. (2008). Beyond Self-Assessment: Assessing organisational cultural responsiveness. Journal of Cultural Diversity, 15(1), 7-15.

15. Brach, C., \& Fraser, I. (2000). Can Cultural Competency Reduce Racial And Ethnic Health Disparities? A Review And Conceptual Model. Med Care Res Rev, 57(Supplement 1), 181-217.

16. Burton, C. (1995). Managing for diversity: report to Karpin. In E. Davis \& C. Harris (Eds.), Making the Link, no. 6 Sydney: Affirmative Action Agency and the Labour Management Studies Foundation.

17. Buttner, E. H., Lowe, K. B., \& Billings-Harris, L. (2010). The Impact of Diversity Promise Fulfillment on Professionals of Color Outcomes in the USA. Journal of Business Ethics, 91(4), 501-518.

18. Buttner, E. H., \& Lowe, K. B. (2010). Diversity climate impact on employee of color outcomes: does justice matter? Career Development International, 15(3), 239-258.

19. Chipps, J. A., Simpson, B., \& Brysiewicz, P. (2008). The Effectiveness of Cultural-Competence Training for Health Professionals in Community-Based Rehabilitation: A Systematic Review of Literature. Worldviews on Evidence-Based Nursing 5, 85-94.

20. Cox, T. J. (1991). The multicultural organization. Academy of Management Executive, 5(2), 34-47.

21. Cox, T. J. (1993). Cultural Diversity in Organisations: Theory, Research and Practice. San Francisco: Berrett-Koehler Publishers.

22. Cox, T. J., \& Nkomo, S. M. (1990). Invisble men and women: A status report on race as a variable in organization behavior research. Journal of Organizational Behavior, 11, 419-431.

23. Creegan, C., Colgan, F., Charlesworth, R., \& Robinson, G. (2003). Race Equality Policies at Work: Employee Perceptions of the 'Implementation Gap' in a UK Local Authority. Work Employment Society, 17, 617-640.

24. Cross, T., Bazron, B., Dennis, K., \& Issacs, M. (1989). Towards a Culturally Competent System of Care (Vol. 1). Washington, DC: Georgetwon University Child Development Center, CASSP Technical Assistance Center.

25. Curtis, E. F., \& Dreachslin, J. L. (2008). Integrative Literature Review: Diversity Management Interventions and Organizational Performance:A Synthesis of Current Literature. Human Resource Development Review, 7(1), 107-134. 
26. De Castro, A. B., Rue, T., \& Takeuchi, D. T. (2010). Associations of Employment Frustration with SelfRated Physical and Mental Health Among Asian American Immigrants in the U.S. Labor Force. Public Health Nursing, 27(6), 492-503.

27. Deitch, E. A., Barsky, A., Butz, R. M., Chan, S., Brief, A. P., \& Bradley, J. C. (2003). Subtle yet significant: The existence and impact of everyday racial discrimination in the workplace Human Relations, 56(11), 1299-1324.

28. Din-Dzietham, R., Nembhard, W. N., Collins, R., \& Davis, S. (2004). Perceived stress following racebased discrimination at work is associated with hypertension in African Americans: The metro Atlanta heart disease study. Social Science \& Medicine 58, 449-461.

29. Dreachslin, J. L. (1999). Diversity leadership and organizational transformation: Performance indicators for health services organizations. Journal of Healthcare Management, 44(6), 427-439.

30. Dreachslin, J. L., Weech-Maldonado, R., \& Dansky, K. H. K. H. (2004). Racial and ethnic diversity and organizational behavior: a focused research agenda for health services management. Social Science \& Medicine, 59(5), 961-971.

31. Dunn, K. (2003). Racism in Australia: findings of a survey on racist attitudes and experiences of racism. Paper presented at the The Challenges of Immigration and Integration in the European Union and Australia, 18-20 February 2003, University of Sydney, Australia

32. Ely, R. J. (2004). A field study of group diversity, participation in diversity education programs, and performance. Journal of Organizational Behavior, 25(6), 755-780.

33. Ely, R. J., \& Thomas, D. A. (2001). Cultural Diversity at Work: The Effects of Diversity Perspectives on Work Group Processes and Outcomes. Administrative Science Quarterly, 46, 22-273.

34. Executive Leadership Foundation. (2003). ProMosaic ${ }^{\mathrm{TM}}$ II, Diversity/Inclusion Assessment Tool. Retrieved from http://www.promosaic.org/

35. Fine, M. G. (1996). Cultural diversity in the workplace: the state of the field The Journal of Business Communication, 33(4), 485-503.

36. Fine, M. G., Johnson, F. L., \& Ryan, M. S. (1990). Cultural diversity in the workplace. Public Personnel Management, 19(3), 305-319.

37. Geron, S. (2002). Cultural Competency: How Is It Measured? Does It Make a Difference? Generations, 26(3), 39-45.

38. Gozu, A., Beach, M. C., Price, E. G., Gary, T. L., Robinson, K., Palacio, A., .. . Cooper, L. A. (2007). SelfAdministered Instruments to Measure Cultural Competence of Health Professionals: A Systematic Review. Teaching and Learning in Medicine: An International Journal, 19(2), 180 - 190.

39. Griffith, D. M., Childs, E. L., Eng, E., \& Jeffries, V. (2007). Racism in organizations: the case of a public health department. Journal of Community Psychology, 35(3), 287-302.

40. Griffith, D. M., Yonas, M. A., Mason, M., \& Havens, B. E. (2010). Considering Organizational Factors in Addressing Health Care Disparities: Two Case Examples. Health Promotion Practice, 11(3), 367-376.

41. Harper, M., Hernandez, M., Nesman, T., Mowery, D., Worthington, J., \& Issacs, M. (2006). Organizational cultural competence: A review of assessment protocols (Making children's mental health services successful series, FMHI pub. no. 240-2). Tampa, Florida: University of South Florida, Louis de la Parte Florida Mental Health Institute, Research \& Training Center for Children's Mental Health.

42. Hernandez, M., Nesman, T., Mowery, D., Acevedo-Polakovich, I., \& Callejas, L. (2009). Cultural Competence: A Literature Review and Conceptual Model for Mental Health Services. Psychiatric Services, 1046-1050.

43. Holder, J. C., \& Vaux, A. (1998). African American Professionals: Coping with Occupational Stress in Predominantly White Work Environments. Journal of Vocational Behaviour 53(315-333).

44. International Labour Organization (ILO). (2008). Practice Database. http://www.ilo.org/public/english/protection/migrant/equality/database/index.htm

45. Ivancevich, J. M., \& Gilbert, J. A. (2000). Diversity Management: Time for a New Approach. Public Personnel Management, 29(1), 75-92.

46. Jackson, S. E., Joshi, A., \& Erhardt, N. L. (2003). Recent research on team and organizational diversity: SWOT analysis and implications. Journal of Management, 29(6), 801-830.

47. Kalev, A., Dobbin, F., \& Kelly, E. (2006). Best Practices or Best Guesses? Assessing the Efficacy of Corporate Affirmative Action and Diversity Policies. American Sociological Review 71, 589-617.

48. Katz, D., \& Kahn, R. L. (1978). The Social Psychology of Organizations. New York: Wiley. 
49. Kessler, R. C., Mickelson, K. D., \& Williams, D. R. (1999). The prevalence, distribution, and mental health correlates of perceived discrimination in the United States Journal of Health and Social Behavior, 40(3), 208-230.

50. Kochan, T., Bezrukova, K., Ely, R., Jackson, S., Joshi, A., Jehn, K., . . Thomas, D. (2003). The effects of diversity on business performance: Report of the diversity research network. Human Resource Management, 42(1), 3-21.

51. Kossek, E. E., \& Zonia, S. C. (1993). Assessing diversity climate: A field study of reactions to employer efforts to promote diversity. Journal of Organizational Behavior, 14, 61-81.

52. Krieger, N., Kaddour, A., Koenen, K., Kosheleva, A., Chen, J. T., Waterman, P. D., \& Barbeau, E. M. (2011). Occupational, social, and relationship hazards and psychological distress among low-income workers: Implications of the 'inverse hazard law'. Journal of Epidemiology and Community Health, 65(3), 260-272.

53. Kulik, C. T., \& Roberson, L. (2008). Common Goals and Golden Opportunities: Evaluations of Diversity Education in Academic and Organizational Settings. Academy of Management Learning \& Education, 7(3), 309-331.

54. Kumas-Tan, Z., Beagan, B., Loppie, C., MacLeod, A., \& Frank, B. (2007). Measures of cultural competence: Examining hidden assumptions. Academic Medicine, 82(6), 548-557.

55. LaVeist, T. A., Richardson, W. C., Richardson, N. F., Relosa, R., \& Sawaya, N. (2008). The COA360: A Tool for Assessing the Cultural Competency of Healthcare Organizations. Journal of Healthcare Management, 53(4), 257-267.

56. Leiderman, S., \& Dupree, D. M. (2005). Looking Back: Project Change from 1991-2005. Conshohocken, PA: Center for Assessment and Policy Development (CAPD).

57. Lie, D. A., Lee-Rey, E., Gomez, A., Bereknyei, S., \& Braddock, C. H. (2011). Does Cultural Competency Training of Health Professionals Improve Patient Outcomes? A Systematic Review and Proposed Algorithm for Future Research. Journal of General Internal Medicine, 26(3), 317-325.

58. Liff, S., \& Wajcman, J. (1996). 'Sameness' and 'Difference' Revisited: Which Way Forward For Equal Opportunity Initiatives? Journal of Management Studies, 33(1), 79-94.

59. Littrell, L. N., \& Salas, E. (2005). A Review of Cross-Cultural Training: Best Practices, Guidelines, and Research Needs. Human Resource Development Review, 4(3), 305-334.

60. Lorbiecki, A., \& Jack, G. (2000). Critical Turns in the Evolution of Diversity Management. British Journal of Management, 11(Special Issue), 17-31.

61. Mason, J. L. (1995). Cultural Competence Self-Assessment Questionnaire: A Manual for Users. Retrieved from http://www.eric.ed.gov/ERICDocs/data/ericdocs2sql/content_storage_01/0000019b/80/14/b5/54.pdf

62. Mathews, A. (1998). Diversity: A principle of human resource management. Public Personnel Management, 27(2), 175-185.

63. McLeod, P. L., Lobel, S. A., \& Cox, T. H. (1996). Ethnic diversity and creativity in small groups. Small Group Research, 27, 246-264.

64. NCCC. (2006). Cultural and Linguistic Competence Policy Assessment. Retrieved from http://www.clcpa.info/documents/CLCPA.pdf

65. Nicholas, S., Sammartino, A., O'Flynn, J., Ricciotti, A., Lau, K., \& Fisher, N. (2001). The Business Case for Diversity Management, Programme for the Practice of Diversity Management: Department of Immigration and Multicultural Affairs in cooperation with the Australian Centre for International Business. Available from www.diversityaustralia.gov.au.

66. Office of Minority Health. (2001). National standards for culturally and linguistically appropriate services in health care: Final report. Washington, DC: Office of Minority Health.

67. Olavarria, M., Beaulac, J., Belanger, A., Young, M., \& Aubry, T. (2009). Organizational cultural competence in community health and social service organizations: how to conduct a self-assessment. Journal of Cultural Diversity, 16(4), 140-150.

68. Paluck, E. L. (2006). Diversity Training and Intergroup Contact: A Call to Action Research. Journal of Social Issues, 62(3), 577-595.

69. Paradies, Y., Chandrakumar, L., Klocker, N., Frere, M., Webster, K., Burrell, M., \& McLean, P. (2009). Building on our strengths: A framework to reduce race-based discrimination and promote diversity in Victoria. Melbourne: Victorian Health Promotion Foundation. 
70. Potapchuk, M., \& Aspen Institute Roundtable for Community Change. (2007). Community Change Processes and Progress in Addressing Racial Inequities. Baltimore, MD and New York, NY: MP Associates, Inc. and Aspen Institute Roundtable for Community Change.

71. Prasad, P., Mills, A. J., Elmes, M., \& Prasad, A. (1997). Managing the organizational melting pot: dilemmas of workplace diversity. Thousand Oaks, Calif. : Sage Publications.

72. Richard, O. C. (2000). Racial diversity, business strategy and firm performance: a resource based view. Academy of Management Journal, 43(2), 164-177.

73. Roberson, L., \& Kulik, C. T. (2007). Stereotype threat at work. Academy of Management Perspectives, 21(2), 24-40.

74. Rospenda, K. M., Richman, J. A., \& Shannon, C. A. (2009). Prevalence and Mental Health Correlates of Harassment and Discrimination in the Workplace. Journal of Interpersonal Violence, 24(5), 819-843.

75. Scarville, J., Button, S. B., Edwards, J. E., Lancaster, A. R., \& Elig, T. W. (1999). Armed Forces equal opportunity survey (No. ADA-366037). Arlington, VA: Defense Manpower Data Center.

76. Schneider, K. T., Hitlan, R. T., \& Radhakrishnan, P. (2000). An examination of the nature and correlates of ethnic harassment experiences in multiple contexts. Journal of Applied Psychology, 85(1), 3-12.

77. Shannon, C. A., Rospenda, K. M., Richman, J. A., \& Minich, L. M. (2009). Race, racial discrimination, and the risk of work-related illness, injury, or assault: Findings from a national study. Journal of Occupational and Environmental Medicine, 51(4), 441-448.

78. Shapiro, I. (2002). Training for Racial Equity and Inclusion: A Guide to Selected Programs Washington, DC: Aspen Institute.

79. Siegel, C., Haugland, G., \& Chambers, E. D. (2002). Cultural Competency in Mental Health Systems of Care: Selection and Benchmarking of Performance Measures: The New York State Office of Mental Health, Nathan S. Kline Institute for Psychiatric Research, Centre for the Study of Issues in Public Mental Health.

80. Siegel, C., Haugland, G., \& Chambers, E. D. (2004). Cultural competency assessment scale with instructions: Outpatient service delivery agency level. Orangeburg, NY: Unpublished manuscript, Nathan S. Kline Institute for Psychiatric Research.

81. Soni, V. (2000). A Twenty-First Century Reception for Diversity in the Public Sector: A Case Study. Public Administration Review, 60(5), 395-408.

82. Sue, D. W., Carter, R. T., Casas, J. M., Fouad, N. A., Ivey, A. E., \& Jensen, M. (1998). Multicultural Counselling Competencies: Individual and organizational development. Thousand Oaks, CA: Sage.

83. The Lewin Group. (2002). Indicators of Cultural Competence in Health Care Delivery Organizations: An Organizational Cultural Competence Assessment Profile. Retrieved from http://www.culturallycompetentmentalhealthnj.org/docs/2006-12-training/CC-LewinReport.pdf

84. Thomas, R. R. (1990). From Affirmative Action to Affirming Diversity. Harvard Business Review, MarchApril 107-117.

85. Thomas, R. R. (1999). Diversity Management: Some Measurement Criteria. Employment Relations Today, Winter 1999, 49-62.

86. Trenerry, B., Franklin, H., \& Paradies, Y. (2010). Review of audit and assessment tools, programs and resources in workplace settings to prevent race based discrimination and support diversity. Melbourne Victorian Health Promotion Foundation.

87. Triana, M., García, M. F., \& Colella, A. (2010). Managing diversity: How organizational efforts to support diversity enhance affective commitment and reduce turnover intent for employees who experience discrimination at work. Personnel Psychology, 63, 817-843.

88. Vancouver Ministry for Children and Families. (2002). Cultural Competency Assessment Tool. Available from http://www.llbc.leg.bc.ca/public/pubdocs/bcdocs/339295/assessment tool.pdf.

89. Wrench, J. (2005). Diversity management can be bad for you. Race and Class, 46(3), 73-84.

90. Wu, E., \& Martinez, M. (2006). Taking Cultural Competency from Theory to Action. California: California Pan-Ethnic Health Network. 